Article

\title{
Living Joyfully after Losing Social Hope: Kierkegaard and Chrétien on Selfhood and Eschatological Expectation
}

\section{J. Aaron Simmons}

Department of Philosophy, Furman University, Greenville, SC 29613, USA; aaron.simmons@furman.edu; Tel.: +1-864-294-3526

Academic Editor: Justin Sands

Received: 18 January 2017; Accepted: 22 February 2017; Published: 24 February 2017

\begin{abstract}
In this essay, I offer an existential-phenomenological consideration of what it might look like to live joyfully after losing social hope. Using the example of the widespread hopelessness that many are feeling in light of the election of Donald Trump, I suggest that the danger of losing hope is that we can also lose our selfhood in the process. In order to develop a conception of "eschatological hope" that would be resistant to the loss of such social and political expectations, I draw specifically on Søren Kierkegaard's notion that "the expectancy of faith is victory," and Jean-Louis Chrétien's idea of "the unhoped for," in order to develop a model of hope that remains when it seems like all other hope has been lost. Rather than being overcome by anxiety about the future, eschatological hope fosters joy in the present.
\end{abstract}

Keywords: hope; eschatology; joy; subjectivity; Søren Kierkegaard; Jean-Louis Chrétien; David Kangas; Claude Romano; phenomenology; philosophy of religion

This essay is dedicated to the memory of my mentor and friend, David Kangas, for whom the eschaton is now a reality rather than merely a hope. He not only taught me to read Kierkegaard, but also how to live.

\section{Introduction: On the Occasion of a New Year}

I write this essay at the turn of a new year. The calendar now reads 2017, but I wonder how different things are now from so many years that have gone before. It seems that the occasion of a new year is always an opportunity not only for reflection, but also for new decisions about what lies ahead. At the beginning of each new year, I try to read Søren Kierkegaard's Upbuilding Discourse "The Expectancy of Faith," which he wrote on the occasion of New Year's Day and published in 1843 [1]. Kierkegaard's take on the possibilities of the new in light of the failures of the old always helps me put into appropriate perspective the stakes of living faithfully in light of current social challenges. ${ }^{1}$ As is often the case for his Discourses, he begins with a prayer. Listen to part of what he says there:

The new year faces us with its requirements, and even though we enter it downcast and troubled because we cannot and do not wish to hide from ourselves the thought of the lust of the eye that infatuated, the sweetness of revenge that seduced, the anger that made us unrelenting, the cold heart that fled far from you, we nevertheless do not go into the new year entirely empty-handed, since we shall indeed also take along with us recollections of the fearful doubts that were set at rest, of the lurking concerns that were

1 For more on Kierkegaard's notion of expectancy and the theological ramifications of newness, see [2,3]. 
soothed, of the downcast disposition that was raised up, of the cheerful hope that was not humiliated ([1], p. 7; emphasis added).

In light of the recent election of Donald Trump as the President of the United States, I also enter the current year "downcast and troubled" and share Kierkegaard's prayer, his hope, for something that will remain stable despite the anxiety regarding an uncertain future. ${ }^{2}$ According to Kierkegaard, the expectancy of faith is victory, which sounds great, but does this ultimately amount to a disregard for and detachment from worldly affairs? If such quietism is the upshot of the expectancy of faith, how are we to avoid the dangers of an unfeeling theodicy? ${ }^{3}$ Is it possible to keep expecting an eschatological victory while losing social hope in a way that motivates joyful living in relation to the works of love and justice? ${ }^{4}$

These are important and difficult questions and answers to them are not obvious. Nonetheless, I will argue that, in light of Kierkegaard's account, we should realize that the hope that keeps us "cheerful" is a hope rooted in the expectation resulting from faithful existence, not the anticipation of successful social programs. Indeed, for Kierkegaard, it is only grounded in the eternal, as understood according to God's own faithfulness and goodness, that we can find continued cause to work diligently in the present, motivated by the call of faithfulness to live passionately in the present. In this way, I find Jean-Louis Chrétien's phenomenological analysis of the "unhoped for," when read alongside Kierkegaard's suggestion that it is an "upbuilding" thought to realize that "in relation to God we are always in the wrong" ([8], pp. 339-54), to be an especially helpful framework for living a life of expectation even after losing one's determinate social hopes for the future. Ultimately, drawing on Kierkegaard and Chrétien, I will suggest that when we lose hope in that which is not eternal, we are eternally repositioned in relation to the "victory" that should be our eschatological orientation in the first place. We are, thus, upbuilt because we no longer rest our hopes upon our own abilities, but instead situate our existence in relation to that which calls us beyond ourselves. As we will see, such an eschatological orientation makes humility the key to the confidence of faith and the joy that results from it. Ultimately, eschatological hope is not an obstacle to social progress, but instead yields a renewed vigor for engaged social life because we are no longer defined by bringing about specific outcomes, but instead by working faithfully toward excessive love and plentiful justice.

Before beginning in earnest, let me offer a few methodological clarifications. First, the following is not intended to be a phenomenology of hope, or even of the loss of hope. Excellent philosophical work has been done in this regard by others and so I will not aim to repeat that work here. ${ }^{5}$ Instead, my goal is more an existential-phenomenological exploration of what it might mean to live faithfully in light of seeming hopelessness. I am primarily interested in what we might term an eschatological orientation for subjectivity that is inaugurated by the loss of a particular expected end. Second, although "victory" for Kierkegaard, and "the unhoped for" for Chrétien, are ultimately Christian eschatological conceptions, my goal here is not to write from the perspective of my own Christianity, but instead from the perspective of a phenomenologist interested in thinking carefully about what it means to make sense of oneself in light of these two conceptions. Namely, I want to figure out how selfhood can be understood as constituted in relation to the joint givenness of both expected victory and also the unhoped for. Though it may be that these two ideas are only plausibly understood internal to a specific

2 For more on the role of hope in Kierkegaard's thought, see especially [4], see also [5,6].

3 Although I think Kierkegaard primarily means that faith expects victory, it is also the case that the phrasing contains an important ambiguity such that the expectancy of faith is itself victory. To live in the expectancy of faith can be viewed as a kind of victory over the anxiety accompanying finite existence. In what follows, I will attempt to keep this ambiguity in play.

4 For more on this relationship between love and justice, see [7].

5 As a particularly good phenomenological consideration, see [9,10]. Additionally, see [11] for a Sartrean account of hope, [12] for a Kantian phenomenology of hope, [13] as a model of how to consider hope in the context of Bloch's phenomenology of death, [14] as an example of why hope can be contrasted with a phenomenology despair, and [15] for a politics of hope in light of Levinas. 
conception of determinate religion (what Jean-Luc Marion might term the counter-intentionality of a horizon-less religious phenomenality), ${ }^{6}$ I will not address that question here, but instead work from a conditional acceptance of both as part of embodied existence that is at least possibly the case for a great number of existing individuals. My question is best philosophically stated as follows: If Kierkegaard and Chrétien are right about the importance of eschatological hope, then what follows for how we ought to understand ourselves here, now, as faithfully expecting victory although standing at the precipice of hopelessness?

\section{Losing Hope, Losing Ourselves}

In a recent interview with Oprah Winfrey, Michelle Obama reflected on the election of Donald Trump as President of the United States. Her assessment of the situation displays a profound existential awareness of the relationship between self-identity and hope:

We feel the difference now. See, now, we are feeling what not having hope feels like... Hope is necessary. It's a necessary concept and Barack didn't just talk about hope because he thought it was just a nice slogan to get votes... He and I and so many believe that-what else do you have if you don't have hope?... What do you give your kids if you can't give them hope [17]? ${ }^{7}$

What Michelle Obama rightly realizes is that when one loses hope what gets lost is not simply one's idea of what the future was going to be like, but instead one's idea of oneself in relation to what matters. ${ }^{8}$ When she asks "what do you give your kids if you can't give them hope?", she effectively identifies the way in which hope forms what we might phenomenologically term the horizon of expectation against which selfhood is not only understood, but constituted. ${ }^{9}$ Martin Heidegger expresses this basic idea when he claims that "Dasein 'is' its past in the manner of its being which, roughly expressed, on each occasion 'occurs' out of its future" ([21], p. 19). In other words, things are defined in retrospect in relation to what will eventually be the case about them.

Kierkegaard says something similar to Heidegger when he famously suggests that we live forwards, but only understand backwards. In this way, we can appreciate that the unexpected forms the context in which we define our orientation toward what we do expect. Things might not occur as predicted and so only after the fact are we in a position to decide what the fact is about what has occurred. In the midst of things, as poor existing individuals, as Kierkegaard might say, we are always only ever to do the best that we can in relation to what we hope will turn out not only to be the case, but also will turn out to have been the case. Accordingly, how we take ourselves up relative to our future affects what our past will mean for us. We might understand this as something of an existential conception of the noetic effects of finitude.

Let me offer just one mundane example of this broader existential idea. When I was in college, I lived in relation to the hope that I would eventually go to graduate school and receive my Ph.D. That hope made not only what I was doing presently matter relative to an expected end, but it also made what I had done to get to that point meaningful in a particular way relative to this horizon of expectation by which I interpreted it. In many ways, as Catherine Pickstock suggests [22], it is only as repeated, i.e., as fulfilled in time, that identity in relation to such expectations gets stabilized in particular ways. ${ }^{10}$

6 For a sustained consideration of what such counter-intentionality might involve in the frame of new phenomenology, see [16].

7 This interview with Michelle Obama received widespread media attention, but has not yet being the object of philosophical analysis. In what follows, I hope to provide such engagement.

8 For a discussion of philosophical accounts of hope in relation to Barack Obama's emphasis on the idea of hope during his presidency, see [18].

9 For phenomenological considerations of such a possible horizon, see [19]. See also, [20].

10 For my more detailed analysis of Pickstock's account, see [23]. 
Things get complicated, though, when one loses hope in a determinate expectation for future events. When that toward which you were orienting your thought and action no longer seems possible, then the loss is not merely something that requires a readjustment of the object of one's temporal desire (e.g., instead of the Ph.D., perhaps I will go to med school), but also requires an existential realignment of one's own subjectivity. In some sense, we might say that the loss of hope does not simply require rethinking one's future, but also reinterpreting one's past in order to inhabit one's present otherwise. Importantly, though, expectation does not happen in a vacuum. All expectation occurs relative to some concrete context (social, cultural, ecclesial, liturgical, ideological, etc.) in which one's past is currently interpreted and one's present is currently made manifest, as such. Understandably, then, changes in one's context can affect the legitimacy or plausibility of one's expectation and one's identity as a result.

Let's pursue this thought a bit further. Consider my passing reference to Heidegger above. In citing his work, I find myself in a position of difficulty that I would not have faced just a few years ago prior to the publication of his Black Notebooks, which are texts that reveal the depth of his anti-Semitism. ${ }^{11}$ In this sense, my historical context in relation to the accepted interpretation of Heidegger's philosophy has shifted the expectation that I have about the value and likely consequences of citing him in a paper such as this. Will my reference to Heidegger lead to a better understanding of the point I am trying to make? Or will it simply cause some readers to immediately turn away from my essay due to their own decision to no longer engage with Heidegger? These questions occur in reference to my horizon of expectation, which is never singular and isolated unto itself. This horizon is, like all other phenomenological horizons, fundamentally shared among those who form the discursive "world" in which I find myself. Accordingly, "Heidegger" is not a stable identity, but rather a contested one that depends upon the interpretive frame that currently forms the context of my own current professional community's understanding of what "Heidegger" means.

Expanding out from Heidegger scholarship to the current American political context in light of the Trump election, I am not able to rest comfortably in my hope for this paper due to the context in which it is being written. Simply put, my political horizon of expectation is currently shaking and shifting under my/our feet. Will this paper end up being a timely model of how phenomenology can speak to current world affairs? Will it end up looking quickly dated (or even out of date) due to the specific local situation in which I am attempting to situate my broader phenomenological reflections about faithful existence and the humility that is central to eschatological expectation? Perhaps it will stand as a timeless example of why thinking about existence is always situated, and what matters is not the specific situation, but the way of relating to it as simply one more instance of what is shared about embodiment, finitude, and loss? Well, all I can say is that I don't know. We will have to wait for what will turn out to be the case about the world to see whether my analysis of it will be relevant or not. But, here and now I can (and perhaps must) continue to hope that it will be relevant in order for me to continue writing in light of that expectation.

Nonetheless, as I presently understand things, Michelle Obama's comments to Oprah are not simply a helpful way of framing a phenomenological consideration of hope, but instead highlight the concrete socio-historical situation that also forms part of the lived context in which this paper occurs as, itself, an expression of hope-if not a hope for a specific political outcome or social vision, at least a hope for how philosophically to understand how one might relate to the loss of such things. My use of the election of Donald Trump is not meant to be somehow unique, and hopefully does not simply reflect an overblown case of my own liberal handwringing. Rather, I appeal to it as merely one possible instance of how losing hope might occur, and is presently occurring for a significant number of people. There are numerous, and many more pressing, instances of what losing hope might involve (e.g., a cancer diagnosis, the death of a loved one, the continued realities of racial marginalization, becoming a refugee due to global violence, etc.), but I use Trump here as a helpful case study because I

11 For more on this interpretation of Heidegger, see [24]. 
am convinced that he presents real dangers not only for the future of global politics, but also for how we navigate our own subjectivity in light of that future. For those of us who find Trump to represent a loss of hope in socio-cultural progress (at least for the near term), making sense of Trump is more a matter of making sense of who we are in light of him. Again, with the shaking of our expectations due to a loss of hope comes a shaking in our relationship to ourselves. Perhaps this is why when Gabriel Marcel offers a "metaphysic of hope," he does so by understanding humanity according to the model of essentially being a "traveler" (homo viator) [25]. ${ }^{12}$

Now, importantly, we must tread carefully here in order not to give Trump more power than he deserves. How ought we relate to someone who embodies the loss of a particular sort of social hope without thereby allowing that person to become the standard of meaning, truth, and identity in the process (even if only understood according to a framework of ressentiment)? Said slightly otherwise, and a bit more theologically, how can we take Trump seriously as having the power to change the world and our conception of ourselves within it, without allowing him to become an idol in relation to which we (re)structure our faith? It is here that we can see that these questions are of philosophical importance far beyond the specifics of the current American political situation. They are questions that get at the heart of how to understand oneself and one's world when the expected end toward which one was striving is no longer in place. We might say that they bear upon the very possibility of an eschatological rethinking of hope because they bring us into contact with the spectral notion of hoping "against all hope" (Romans 4:18, NIV). ${ }^{13}$

I am not sure that I have good answers to these questions, but I do think that even when the social situation seems most uncertain and our selfhood most upended as a result, we must resist the temptation to abandon the commitment to the importance of philosophy to the task of meaningful existence. In other words, I hope that losing hope about some things does not entail being hopeless about everything. As such, I hope that C.S. Lewis was right in "Learning in Wartime" when he suggests that it is essential to continue to think well when it seems like everyone around you has stopped thinking [28]. Moreover, I hope he is correct in his assessment that facing an existential threat should not lead to abandoning one's existential priorities. When one's life is at risk, I hope that I am right to believe that, at that very moment, it is most important to embody what makes life worth living. Indeed, in many ways, it is this hope that allows selfhood to continue as a concrete and lived response to the loss of one's expected future.

I do not think that Trump deserves to be understood as tantamount to the existential threats of WWII that formed the context in which Lewis was writing, at least not yet. But, in this time of the "at least not yet," we have the opportunity to think seriously about what Michelle Obama refers to as what it "feels like to lose hope." Maybe in doing so, we can find a space in which to contend that not all hope is lost? I think that we can. But this calls for an eschatological awareness that situates expectation in relation to something that is not subject to the shifting sands of temporal externality. In the face of losing hope, one faces losing oneself, but as Kierkegaard helps us to see, it is when the risk is highest that we can find ourselves in faith such that we joyfully remain defined by that "cheerful hope that was not humiliated."

\section{Expectation ... Eschatological and Otherwise}

Given the importance that hope plays in all aspects of our lives, it is unsurprising that there has recently developed quite a substantive philosophical literature on hope. In addition to classical philosophical considerations such as those offered by Ernst Bloch [29] and Gabriel Marcel [25,30], many contemporary discussions of hope occur in light of mere suggestions of the importance of hope in the

12 For a wide-ranging discussion of Marcel's philosophical authorship that situates his conception of homo viator in relation to other themes in his work, see [26].

13 For a substantive consideration of "hoping against hope," see [27]. 
thought of thinkers such as Aristotle, Aquinas, and Kant. Additionally, although there are some general accounts offered [31-34], numerous essays concern either a particular application of hope to some applied issue (for example, in relation to health care, see [35-37]; in relation to environmental ethics, see [38]; and in relation to educational pedagogy, see [39]), or in relation to some other philosophical notion-especially the relationship of hope to virtue (see, [40-45]). In light of this expanding literature, it can quickly seem difficult to find a way into the debates without getting repetitive, or simply being critical of the accounts already offered. Despite such important scholarship in this area, there is not much that focuses on the impact of the loss of hope on the construction of selfhood, and even less that explicitly connects the loss of social hope to the idea of the expectancy of faith. So, in order to offer an existential-phenomenological contribution to the existing literature, I will begin by looking at Claude Romano's suggestion that there are two types of expectancy, in general, in order then to turn to Kierkegaard's account of the expectancy of faith, in particular [46,47].

Romano helpfully distinguishes between two sorts of awaiting/expecting. The first he describes as "a permanent disposition" and suggests that it is "at work in all perception in all behavior, in all speech" ([46], p. 36). Alternatively, there is a mode of awaiting in which we are "turned and directed toward the future, and to which a certain event, if it takes place, would correspond" ([46], p. 36). The former sort of awaiting might be understood as an existential mode of "anticipation" in which there is no non-temporal context in which I can stand in relation to the world, myself, and others. The latter sort of awaiting can be viewed as "a particular attitude, an existentiell posture that one adopts from time to time" ([46], p. 36). For example, I can expect to go home after I finish writing this paper, but that is not, of itself, a permanent structure of my existence. Yet, that I tacitly anticipate the next minute that I will be alive, the next word I will write, and the next room I would enter when I leave my office are all phenomenological dimensions in which consciousness is temporally situated. The horizon of expectation to which I have referred would correspond to Romano's first sort of expectation, and the specific end motivates a particular belief or action (such as legal protections for undocumented immigrants in America that recognize the fundamental moral dignity of their personhood, say), would correspond to the latter. On this dual model, the existential sort of expectation would remain even if all existentiell specifics get radically challenged by one's lived context.

Given these two alternatives, it remains an open question whether existential anticipation can exist as an empty category, or if it is merely the frame that is necessarily filled by some specific existentiell content presently hoped for. As a structural component attending to the temporality and finitude of human existence itself, I take it that this existential expectation is not merely a place-holder, but instead is the condition for temporal consciousness as a lived reality. Even though I live toward (and in that sense, anticipate) the next moment, or the room down the hall if I were to walk in that direction, or the next word in this sentence if I stop to think about it in an intentional way (which I am now doing and so writing these words has become a strange experience indeed), this doesn't mean that I am actively taking myself up in relation to these anticipated possibilities. Instead, I take Romano's point to be that there must be two very different notions of expectation in play in order for the existentiell orientation to be concretely adopted "from time to time." Thus, I propose that there are two aspects to such determinate existentiell expectation. Let's term the first the volitional component and the second the epistemic component.

The volitional component amounts to the idea that there is a willful decision that allows the existentiell specifics to be taken up as different from other alternatives. So, although I might care about working for legal protections for undocumented immigrants, say, I might allow that to take a backseat in my thought and action (and the resulting conception of my selfhood in relation to it) if I also believe that the dangers of climate change pose a greater threat to the moral dignity of the people on whose behalf I am attempting to work. In this sense, the specifics of my hope for a better immigration policy might remain in place as desirable, but it would not be overriding as the expected end toward which I orient my own existence at this present time-instead, working to lower global carbon emissions would function in this way. Yet, perhaps we are successful in lowering such emissions. In that case, I might 
then turn back to immigration as the hope toward which I live at that time. It also seems possible that there would be times when such hopes are not the most pressing way of making sense of myself at all. Existential anticipation would continue to function in those times such that I have self-identity through time, even if the specifics of my self-identity as oriented toward a specific existentiell outcome are indeterminate-indeed, this might be the best phenomenological way to understand the possibility of leisure, for example.

Alternatively, the epistemic component of existentiell anticipation concerns the idea that there must be evidential support for the possibility of actually achieving the specific outcome toward which one strives. Such evidential warrant allows for a particular instance of existentiell expectation to be a reasonable hope, rather than merely wishful thinking. For instance, I might desire a new truck today, but if I lack the money to pay for it, living toward that expectation is unreasonable because I do not have the required evidence supporting my belief that it is possible to actualize it-so my wish is unable to be transformed into a hope. Importantly, the volitional component of existentiell expectation depends upon the epistemic component. Willfully deciding to orient one's belief and action toward a specific end requires that it be possible to achieve that end-however unlikely it might seem. As with most things that concern belief and action, evidence matters not only in relation to decisions about what is possible, but also regarding decisions about what is most urgent. It is due to a careful consideration of the evidence that one chooses to work for reform in immigration policy as opposed to reducing carbon emissions, or vice-versa. Without such a concern for evidence, our otherwise well-intentioned existentiell expectation might turn out to be not much more than self-absorbed wishing for a world that is made in our own image. Hence, responsible existentiell hoping requires that we be evidentialists at least in this area of our lives.

With these two aspects of existentiell expectation in place, we can better understand its relation to existential anticipation as a structure of temporal consciousness. We are never able to exist without the existential horizon of expectation, but depending on our specific socio-cultural-historical context, existentiell expectation may or may not be activated in our lives such that it shapes our self-identity as a result. We should ask at this point whether or not this dual model of expectation is sufficient for understanding expectation in all its forms. I do not think that it is. There remains a notion of expectation that is neither a structure of temporal consciousness nor a specific mode of historical existence taken up at a particular time. It is this third alternative that, I believe, allows us to retain hope despite losing it and to live victoriously even amidst temporal frustration. Working in light of Kierkegaard, I will term this third model of expectation eschatological since it is not primarily a matter of one's lived historical possibilities, but instead a framework by which one's historical possibilities are reconsidered as non-ultimate.

David Kangas offers an excellent analysis of Kierkegaard's account of expectancy that highlights the central aspects of it that are relevant to our consideration here: The expectation of victory, which Kierkegaard carefully distinguishes from wish-fulfillment, is emblematic of the kind of affectation he links to religion. It is not an emotion, however, that is simply had. Inseparable from a "virtue," it is an emotion that must be won through a difficult praxis of leaning to affirm the future as the incalculable, the unforeseeable. To affirm what is coming, in the absence of any knowledge of it, is for Kierkegaard to conquer oneself; it is to go beyond estrangement- to go "beyond" it not by putting it behind one, but rather by wearing it lightly, so to speak. ([3], p. 394)

As Kangas explains, Kierkegaard does not understand the expectancy of faith to be a matter of existentiell possibility or an existential fact of phenomenological consciousness. Instead, it is about the relation to oneself such that the future is no longer the specific object for which one hopes, but rather is that which cannot be tamed within the bounds of evidential strictures on reasonable outcomes. Continuing, Kangas rightly claims that "the affirmation of the future as the incalculable is identical to the affirmation of the present in its basic character as always already 'under way'" ([3], p. 394). Moreover, Kangas concludes: 
Kierkegaard's discourse thus suggests that possibility of living wholly in the present by way of an embrace of the excess of possibility. Expectancy turns to a kind of groundless joy in the present. It is a kind of joy in existence as such, a joy unmediated by the success or failure of projects. ([3], p. 394)

Kierkegaard entirely refigures the idea of the future from a possible existentiell object into a radical openness, and joyful acceptance, of what may come. The unpredictability of the future no longer threatens my identity. I find myself with an eternal identity beyond mere historical determinacy as I live in the present in light of "the excess of possibility."

"How, then, should we face the future?" Kierkegaard asks ([1], p. 19). He does not initially answer with a straightforward reply of do this and say that. Instead, he presents his reader with an analogy of a sailor out on the ocean who, when confronted with "everything ... changing all around him" as the waves rise and fall, "does not stare down into the waves" but instead "looks up at the stars" ([1], p. 19). The sailor does this, Kierkegaard notes, because the stars are "faithful" and do not change ([1], p. 19). Similarly, like the sailor, we are to "conquer the changeable" by virtue of "the eternal," now understood "as the ground of the future" and through which "the future can be fathomed" ([1], p. 19). Due to the faithfulness of God, then, eternity is not only or even primarily of importance when we are finished with finitude, but rather it is the very means by which finitude finds its importance. As such, Kierkegaardian faith is not an escape-hatch by which we flee existence. It is, rather and rightly, an anchor that keeps us tied to existence, but now properly understood as the site for finding ourselves as eternally defined by the relation to God. The knight of faith is eternally positioned in temporality rather than losing herself through the temporary aesthetic desire for something else that is necessarily fleeting. It is for this reason that the evidentialist requirements that attend to all existentiell expectation are inappropriate in relation to the eschatological expectation of victory.

"The reason we so often go astray," Kierkegaard writes, "is that we seek assurance of our expectancy instead of faith's assurance that we have faith. The person of faith demands no substantiation of his expectancy ... Time can neither substantiate nor refute it, because faith expects an eternity" ([1], p. 27). The victory expected by faith is not something threatened by the shifting sands of one's socio-political context, one's material comforts or lack thereof, or one's perceived social status and cultural importance. To think that this victory could be lost along with an expected existentiell outcome would be metaphorically to confuse the changeless stars with the changing waves-it would be to try to navigate by reference to that which is at stake in the navigation, rather than understanding one's horizon as situated in reference to that which makes movement possible. In this way, we can better appreciate the ambiguity in the phrase "the expectancy of faith is victory." On the one hand, faith expects eventual victory in the eschaton. On the other hand, living in the expectancy of faith is itself a matter of living victoriously, here and now, such that the uncertainty of the future is no longer a cause for anxiety. Kierkegaard, hence, offers an existential account of what it can mean to live into the eschatological notion of "already, but not yet."

When we read Kierkegaard's account of eschatological expectation in light of Romano's dualistic structure of expectation, we are able to appreciate the eschatological way in which history is itself resituated in relation to the eternal. Existential anticipation can be understood as a phenomenological structure that reveals the concrete possibility of existentiell expectation (as defined by the volitional and epistemic components) without any reference to eschatological victory. But, without such reference, we seem unable to overcome the fact that the possible loss of determinate hope is devastating to our selfhood. Eschatological expectation, alternatively, allows the horizon of expectation itself to become stable like the stars. In other words, when we expect a particular possible future, we are always oriented toward that which is always changing with the flow of time. When we expect the victory of faith, and thus faithfully live in victory, we are oriented toward that which is not overcome by the unstable concrete particulars of the social world. Accordingly, when we find ourselves in eschatological hope, we are not defeated by despair and not lost in anxiety due to the continuously shifting sands of socio-historical situations. Neither are we absorbed by the project of wish-fulfillment, however. 
For Kierkegaard, it is specifically due to the permanence of God's goodness (which is metaphorically stable like the stars) that we find the joy of eternity amidst the pains of temporality (as the metaphorical waves continue to crash around us). It is for this reason that the eternal is not simply an empty negation of temporality, but the positive content of divine faithfulness.

In addition to these concerns about selfhood, there are also other important aspects that should not be missed. Were there no eschatological hope, were there no positive eternal victory, then due to the way in which existentiell expectation functions, we would risk only finding selfhood at the cost of other people losing theirs. Only eschatological hope, it seems, is able to avoid the economic logic of lack. Bringing about one particular existentiell end comes at the cost of failing to bring about other possible ends. Eschatologically, however, the existentiell ends toward which we aim are never our ultimate goals and so they are neither the source of our identity nor the final objects of our hope. Because it does not depend on that which can be destroyed by the ravages of time, eschatological hope does not participate in a zero-sum game of competition with the hopes of others. I do not achieve this victory because other people have lost theirs. Rather, the expectation of faith allows for a victory that is available for all due to the singular relation in which we all are invited to stand eternally before God, right here where we find ourselves. We might say that, for Kierkegaard, eternity operates according to a divine logic of excess, plenitude, and grace.

Plentitude, by definition, knows no limits. Excess, as such, cannot be contained. The eschatological hope Kierkegaard advocates is manifest in the expectation of the widow for whom the cup continues to run over with oil (2 Kings 4; see also a similar story in 1 Kings 17). According to this divine logic, then, one's hope is never at odds with the hopes of others. Instead, one's hope is actually a hope for others. As Kierkegaard explains in Works of Love, proper self-love occurs in the context of the self-renunciation required to live into neighbor-love [48]. Our neighbors are never the obstacle to the victory expected by faith. Accordingly, eschatological hope enables works of love, rather than acts of self-protection. Eschatological hope thus fosters humility not only regarding our own self-conception, but also in relation to any particular existentiell end as necessary for goodness. Undaunted by what may come, Kierkegaard concludes "The Expectancy of Faith" with one simple word of affirmation for whatever turns out to be the case: "Amen" ([1], p. 29). There is no resignation here; instead, this is an investment in the importance of working toward the not yet as already the case.

\section{Humility in Light of the Unhoped for}

If existential and existentiell expectation both necessarily expect what is possible, then we might say that the eschatological expects what is impossible. Although this is not entirely incorrect, and it is along these lines that the epistemic and economic constraints on existentiell expectation are no longer applicable in the same ways for eschatological hope, I think we should resist the possibility/impossibility distinction here for two reasons. First, the discourse on impossibility is simply overused in recent Continental philosophy of religion and so ends up being imprecisely deployed as a general reference to something that can't quite be named. Unfortunately, this can sometimes lead to slippery arguments and ambiguities that are quite avoidable.

Second, even when very carefully articulated, "impossibility" in a technical phenomenological sense of being a reference to the "excess" of phenomenality in saturated phenomena, or the overflow of sensibility accompanying the idea of the "event," is difficult linguistically to distinguish from "impossibility" in the mundane sense of just not being something that can happen. While there are many cases where using "impossibility" is the best option for the particular argument being offered, when it comes to eschatological hope, I believe that there is a better choice. Rather than saying that we eschatologically hope for the impossible, which again threatens to lead us into the cul-de-sac of anxiety, I suggest that we appropriate the idea of the "unhoped for" offered by Jean-Louis Chrétien (2002). Simply put, eschatological hope is hope in that which always remains unhoped for relative to self-concern and changeable desires for material success. 
Chrétien's consideration of the unhoped for occurs in the context of a broader discussion of the role of memory and forgetting in the constitution of selfhood. Although hope has appeared in a variety of ways throughout his text, it is not until the fourth chapter, "The Sudden and the Unhoped for," that Chrétien digs into the idea in detail. Nicely aligning, on the one hand, with the Kierkegaardian claim that only as grounded in the eternal does the unforeseen and changeable future stand as a cause for joy, and, on the other hand, with Romano's dual account of expectation as rooted in the realities of human finitude, Chrétien begins his analysis of the unhoped for by moving beyond both existential anticipation and also existentiell expectation in the effort of sketching an eschatological notion of hope that, like Kierkegaard, reflects the unchangeableness of the eternal as grounded in the goodness and faithfulness of God. As Chrétien explains:

The excess of the event over the look of expectation can show simply the finitude and fallibility of human understanding. But it can also be understood positively as the mark of an origin that is more than human. Frequently, the radically unforeseen and completely unhoped for character of what happens appears as the signature of divine power at work. Every divine action disturbs: it foils our expectations and our calculations, our hopes and our fears, in a striking manner. ([49], p. 99)

Basically saying that God is trouble, ${ }^{14}$ Chrétien does not interpret this interruption and disturbance as problematic, but instead as the condition for appropriately relating to ourselves as responses to the divine call. "The divine," he writes, "is not solely what escapes our comprehension, but also what advances toward us, seizing us and acting on us in that very escape" ([49], p. 99). Chrétien develops the notion of the call and response structure in detail elsewhere (see especially [51], but also [52]), but here he merely depends on the idea that self-sufficiency is ultimately tantamount to egoistic idolatry ([49], p. 113). As he explains, the response of what we are terming here an eschatological hope is better understood as a "gesture [that is oriented] not so much toward confidence in the gods as toward the uncertainty of life and human knowledge" ([49], p. 103).

When we take up ourselves as humbled by the excessiveness of the unhoped for, and yet necessarily called toward it as our proper orientation, the horizon of expectation that is merely a matter of intentional consciousness is outstripped relative to an eschatological horizon that is defined by a divine gift characterized by the "gratuity of excess" ([49], p. 113). We are, thus, appropriately self-related when we abandon the thought of being the instigator of our own hopes. "To find without seeking," Chrétien explains, "is to let oneself find without having held the initiative. And letting oneself find is endless when it is God who does the finding" ([49], p. 113). Again, Kierkegaard's metaphor is helpful because when the sailor looks at the waves, he is lost amongst them. When he looks up to the stars, he realizes how small the waves actually are-whether or not he makes it back to the shore is no longer the ultimate concern in light of this new awareness.

It might be objected, however, that Chrétien, and perhaps Kierkegaard as well, ultimately threatens selfhood, rather than properly situating it. Indeed, Chrétien does claim that "To know how to hope is to know how to be unable to attain by oneself what one hopes for, and thus also to learn ceaselessly to receive" ([49], pp. 113-14). Perhaps in relation to the unhoped for, eschatological hope is not much more than a religious default setting to be pitied, rather than an achievement to be celebrated. Importantly, though, Chrétien echoes Kierkegaard's view that it is an upbuilding thought to realize that in relation to God we are always in the wrong:

\footnotetext{
14 The idea that God is trouble is also developed in [50].
} 
Th[ese] two seemingly inverse movements-humiliation and uplifting, dejection and exaltation-constitute the space in which the unhoped for is received: together they signify that the unhoped for is not and cannot be our work, they recognize and confess its excessive character. And the thought of the unhoped for goes together with the thought of humility. ([49], p. 108)

For Kierkegaard and Chrétien, properly conceiving of oneself requires being humbled in relation to God. When there is nothing that we can do that is ultimately good in comparison to God's goodness, we no longer rest our hopes on historical achievement, but invest ourselves in history as the space in which we testify to God's faithfulness in the lived example of our faithful expectation.

When we lose the specific hope that we had for the future relative to evidence that makes it no longer reasonable to believe as possible, we also lose the arrogance that we are the key to unlocking the future in a specific way. Far from leading to a life of apathy, quietism, or resignation, however, this humbled self-conception allows us to continue to work for particular futures without being crushed by failing to bring them about. Following Kierkegaard, when we strive to become faithful, we live victoriously here and now, finding energy for continued action in the already victorious goodness of God. When we try to be successful, alternatively, we are always disappointed because we can never do enough.

Becoming faithful is a task for a lifetime and so we are fully positioned as joyfully inhabiting the present as the moment in which we are able to live toward the unhoped for as the victory that defines where we already are. But, how do we do this in concrete ways? We continue to realize that it matters that we live purposefully here and now toward particular existentiell ends, but without allowing those ends to be ultimately determinative for who we are. Returning to the sailor, he does still hold the existentiell hope to make it through the storm, but rather than fear overtaking him as he looks at the roaring seas, he realizes that the stars are still visible and so he keeps trying to move in the right direction as long as he can. In this way, he does not abandon his existentiell hopes, but understands that they are most effectively pursued when he is no longer exclusively devoted to bringing them about.

Under the pseudonym of Johannes de Silentio, Kierkegaard illustrates nicely the idea of continuing to hold onto one's existentiell expectation while resituating it as fleeting in relation to the ultimate by which one finds true joy. Describing the ways in which the knight of faith is always unrecognizable from the outside, Silentio writes:

Toward evening, he goes home, and his gait is as steady as a postman's. On the way, he thinks that his wife surely will have a special hot meal for him when he comes home-for example, roast lamb's head with vegetables ... It so happens that he does not have four shillings to his name, and yet he firmly believes that his wife has this delectable meal waiting for him. If she has, to see him eat would be the envy of the elite and an inspiration to the common man, for his appetite is keener than Esau's. His wife does not have it—curiously enough, he is just the same. ([53], pp. 39-40; emphasis added)

Two things are worth noting here. First, the man is said not to have enough money to purchase the lamb, but even so he believes that it will be waiting for him when he gets home. Earlier I suggested that existentiell hope requires an epistemic justification in order for it to be distinguished from mere wishing. Yet, in light of the reorientation that this man receives due to his faith, even what might be understood as hopeless according to a worldly logic of economic lack is now legitimately expected according to the plentitude of the logic of excess. Perhaps we might say that it is due to eschatological hope that miracles are possible in the realm of existentiell events. However, Silentio does not give in to the temptation of concluding that since in faith "all things are made possible" (Matthew 19:26, NIV), that somehow the knight of faith is lifted above the messiness of embodied existence. Rather than being lifted out of existential difficulties, we are thrown back into them. But, defined by joy, we are 
able to withstand the anxiety that might otherwise have tempted us to abandon our efforts at striving toward a better world. Joy motivates action. Anxiety generates despair that causes us to give up.

Unsurprisingly, then, the man gets home and there is no roast lamb waiting for him-for his wife didn't have the money to pay for it. Nonetheless, and this is the second thing worth noting, "curiously enough, he is just the same." He is not defeated when his existentiell hope fails. He eats what is prepared. He continues about his day. He realizes that his true identity, his ultimate hope, and his deepest joy, are not dependent on successfully obtaining the thing he had hoped for (viz., the roast lamb's head, or the new truck, or the presidential candidate of his choice), but instead are rooted firmly in that which always remains unhoped for when one's attention is merely directed toward getting more stuff. He is called, named, and defined by the eternal. Whatever he has for lunch, he is not at risk of losing himself. Risk always abounds, but despair has been rooted out by hoping for the unhoped for victory of faith that rejects the economic logic of success.

We can now see how the expectation of faith, which simply is victoriously living toward that which is to come, is not just a new postmodern way of affirming an old, and problematic, theodicy. The victory is not that it all will work out in the end, or that all the evil will turn out to have been part of the unfolding of the good, or that my soul is made better by enduring suffering. Instead, eschatological hope knows that evil continues to exist. Faithfully expecting victory does not mean that we will eventually be winners-that would problematically reinscribe faith back into the zero-sum notion of success. Again, Kierkegaard's notion of faith is not a matter of faith for a different world, but for this world. The expectancy of faith is not merely about an eventual future, but a reimagined present. As we have seen, eschatological hope is not merely for what will ultimately come, but for what already has. Hoping for the unhoped for, therefore, does not yield quietism in the name of some sort of worldly resignation. Rather, it yields a renewed energy for living faithfully in the world. Like the sailor, when the waves crash, we don't jump out of the ship in order to reach the stars. We look to the stars in order to reach the shore.

\section{Conclusions: Finding Joy!}

I am fairly confident that Michelle Obama was not thinking about Kierkegaard or Chrétien during her interview with Oprah. I expect that she was more speaking from her heart about the experience of finding herself facing the increasingly likely future in which all that she and her husband had worked for-the horizon of expectation toward which they have presently lived and through which they have understood their past-would be lost. From the perspective she offers, this is what it feels like to lose hope. It feels like we have lost ourselves. Perhaps not surprisingly, then, despair and anxiety are frequent themes in the writings of the existentialists, who think so carefully about the realities of finitude in relation to the uncertainties of the future.

But, for those who understand themselves according to the victory that is the expectancy of faith, a new hope not only emerges from the ashes of the lost existentiell project, but is now able to be understood as having always been the unhoped for that forms the condition of any particular hope for the world. When we are gripped by the unhoped for, losing hope in the world does not necessarily amount to losing one's footing, but can potentially result in finding one's true ground.

Returning to where we started, I admit that Donald Trump scares me. The current political situation in America is one that is causing me to lose my existentiell hope in the social progress to which I have been hopefully committed. And yet, despite losing such social hope, Kierkegaard and Chrétien offer resources for not ultimately being hopeless. On their model, we can refuse to allow the self-idolatry that is rooted out by eschatological hope to be replaced by a Trump-idolatry of anxiety about the future. They offer the possibility of being eternally grounded in God's faithfulness such that the future is no longer the cause of anxiety, but a source of joy. Eschatological hope is both "cheerful" and "not humiliated" because it is not held by those who operate according to the logic of economic lack whereby success is what defines selfhood, but according to the logic of graceful excess whereby selfhood is a matter of faithful becoming. Idolatry, they contend, is resisted when we are always 
thrown back on our own smallness in relation to the unchangeableness of God's character. When one is made low, it might seem that there is just a shorter distance to fall when knocked down, but actually humility is the key to understanding how to stand tall.

In the end, Kierkegaard and Chrétien provide a model of eschatological hope whereby losing our historical hopes does not yield a disregard for present affairs, but instead propels us ever more passionately into a concern for them and all the neighbors who will be affected as a result of what occurs. We care about where we find ourselves and work toward a better tomorrow for our neighbors because we know that this, here and now, is where we stand joyfully ... come what may. The risk continues, but the worry about failure does not. Work remains to be done, but we are better prepared for the work when we are not overcome by the arrogance of despair. When confronted with evidence that stands as good reason to lose hope, we have a choice of how to respond. Will we lose ourselves with the loss of our expected future, or will we find ourselves as never having been finally threatened by the uncertainty of the future in the first place. This decision is where selfhood truly happens.

In a deeply Kierkegaardian realization, Kangas once wrote that he "considers himself fortunate to have never believed the human condition was 'curable'." When he was diagnosed with stage 4 cancer and only given a short time to live, rather than giving in to absolute despair regarding the literal loss of his future and his life, Kangas was thus able to respond by saying that "in the end there is the unmanageable and we would be trivial beings without it. So, onward with my day!"15 Michelle Obama might be right to say that, in relation to disappointed social and political expectations, what she is feeling is "what it feels like to lose hope," but that exclamation point at the end of Kangas's sentence is what the joy that comes from eschatological hope looks like.

Conflicts of Interest: The author declares no conflict of interest.

\section{References}

1. Kierkegaard, Søren. Eighteen Upbuilding Discourses. Edited and translated by Howard V. Hong and Edna H. Hong. Princeton: Princeton University Press, 1990.

2. Kangas, David. Kierkegaard's Instant: On Beginnings. Bloomington and Indianapolis: Indiana University Press, 2007.

3. Kangas, David. "Kierkegaard." In The Oxford Handbook of Religion and Emotion. Edited by John Corrigan. Oxford: Oxford University Press, 2007, pp. 380-403.

4. $\quad$ Fremstedal, Roe. "Kierkegaard o the Metaphysics of Hope." The Heythrop Journal LIII (2012): 51-60. [CrossRef]

5. Sweeney, Terence. "Hope Against Hope: Søren Kierkegaard on the Breath of Eternal Possibility." Philosophy and Theology 28 (2016): 165-84. [CrossRef]

6. Suzuki, Yusuke. “On Kierkegaard's Religious Crisis in 1848.” The Heythrop Journal 55 (2014): $799-808$. [CrossRef]

7. Minister, Stephen. "Works of Justice, Works of Love: Kierkegaard, Levinas, and an Ethics Beyond Difference." In Kierkegaard and Levinas: Ethics, Politics, and Religion. Edited by J. Aaron Simmons and David Wood. Bloomington and Indianapolis: Indiana University Press, 2008, pp. 229-43.

8. Kierkegaard, Søren. Either/Or Part II. Edited and translated by Howard V. Hong and Edna H. Hong. Princeton: Princeton University Press, 1987.

9. Ratcliffe, Matthew. "What is it to lose hope?" Phenomenology and the Cognitive Sciences 12 (2013): 597-614. [CrossRef]

10. Hodge, Joanna. "Phenomenologies of Faith and Hope." Journal of the British Society for Phenomenology 37 (2006): 37-52. [CrossRef]

11. Aronson, Ronald. "Surviving the Neoliberal Maelstrom: A Sartrean Phenomenology of Social Hope." Sartre Studies International 21 (2015): 21-33. [CrossRef]

15 Quoted from personal correspondence. 
12. Beyleveld, Deryck, and Paul Ziche. "Towards a Kantian Phenomenology of Hope." Ethical Theory and Moral Practice 18 (2015): 927-42. [CrossRef]

13. Terreblanche, Salomon. "Ernst Bloch's 'Laboratorium Possibillis Salutis': On the Humane Ideal in History." Philosophy Today 60 (2016): 277-94. [CrossRef]

14. Steinbock, Anthony J. “The Phenomenology of Despair.” International Journal of Philosophical Studies 15 (2007): 435-51. [CrossRef]

15. Nyar, Jayan. "The Politics of Hope and the Other-in-the-World: Thinking Exteriority." Law and Critique 24 (2013): 63-85. [CrossRef]

16. Simmons, J. Aaron, and Bruce Ellis Benson. The New Phenomenology: A Philosophical Introduction. London: Bloomsbury, 2013.

17. Scott, Eugene. "Michelle Obama: We are feeling what not having hope feels like." CNN Politics, 17 December 2016. Available online: http://www.cnn.com/2016/12/16/politics/michelle-obama-homeoprah-interview / (accessed on 5 January 2017).

18. Woolfrey, Joan. "The Infectiousness of Hope." Philosophy in the Contemporary World 22 (2015-2016): 94-103. [CrossRef]

19. Neal DeRoo, and John Panteleimon Manoussakis, eds. Phenomenology and Eschatology: Not Yet in the Now. Farnham and Burlington: Ashgate, 2009.

20. DeRoo, Neal. Futurity in Phenomenology: Promise and Method in Husserl, Levinas, and Derrida. New York: Fordham University Press, 2013.

21. Heidegger, Martin. Being and Time. Translated by Joan Stambaugh, revised by Dennis J. Schmidt; Albany: State University of New York Press, 2010.

22. Pickstock, Catherine. Repetition and Identity. Oxford: Oxford University Press, 2013.

23. Simmons, J. Aaron. "Kisses Sweeter than...Something: Kierkegaard and Pickstock on Repetition and Revision." Syndicate 2 (2015): 86-97. Available online: https://syndicate.network/symposia/theology/ repetition-and-identity/\#aaron-simmons (accessed on 6 January 2017).

24. Gordon, Peter E. "Heidegger in Black." New York Review of Books, 9 October 2014. Available online: http:/ /www.nybooks.com/articles/2014/10/09/heidegger-in-black/ (accessed on 5 January 2017).

25. Marcel, Gabriel. Homo Viator: Introduction to a Metaphysic of Hope. Translated by Emma Craufurd. London: Victor Gollancz Ltd, 1951.

26. Paul Arthur Schilpp, and Lewis Edwin Hahn, eds. The Philosophy of Gabriel Marcel. La Salle: Open Court, 1984.

27. Caputo, John D. Hoping Against Hope (Confessions of a Postmodern Pilgrim). Minneapolis: Fortress Press, 2015.

28. Lewis, C. S. The Weight of Glory and Other Addresses. New York: HarperCollins, 1980.

29. Bloch, Ernst. A Philosophy of the Future. Translated by John Cumming. New York: Herder and Herder, 1970.

30. Gabriel Marcel, ed. Fresh Hope for the World: Moral Re-Armament in Action. Translated by Helen Hardinge. London: Longmans, 1958.

31. Van Hooft, Stan. Hope. Durham: Acumen, 2011.

32. Waterworth, Jayne M. A Philosophical Analysis of Hope. New York: Palgrave Macmillan, 2004.

33. Shade, Patrick. Habits of Hope: A Pragmatic Theory. Nashville: Vanderbilt University Press, 2001.

34. Godfrey, Joseph J. A Philosophy of Human Hope. Dordrecht: Martinus Nijhoff, 1987.

35. Olsman, Erik, Dick Willems, and Carlo Leget. "Solicitude: Balancing Compassion and Empowerment in a Relational Ethics of Hope-An Empirical-Ethical Study in Palliative Care." Medicine, Health Care, and Philosophy 19 (2016): 11-20. [CrossRef] [PubMed]

36. Barilan, Y. Michael. "From Hope in Palliative Care to Hope as a Virtue and a Life Skill." Philosophy, Psychiatry, and Psychology 19 (2012): 165-81.

37. Stempsey, William E. "Hope for Health and Health Care." Medicine, Health Care, and Philosophy 18 (2015): 41-49. [CrossRef] [PubMed]

38. Clingerman, Forrest, and Verna Marina Ehret. "Hope and Fear: The Theological Side of Framing Environmental Change." Ethics, Policy, and Environment: A Journal of Philosophy and Geography 16 (2013): 152-55. [CrossRef]

39. Webb, Darren. "Pedagogies of Hope." Studies in Philosophy and Education 32 (2013): 397-414. [CrossRef]

40. Lamb, Michael. "Aquinas and the Virtues of Hope: Theological and Democratic." Journal of Religious Ethics 44 (2016): 300-32. [CrossRef]

41. Cobb, Aaron D. “Hope as an Intellectual Virtue? " Southern Journal of Philosophy 53 (2015): 269-85. [CrossRef] 
42. Billingsley, Amy. "Hope in a Vice: Carole Pateman, Judith Butler, and Suspicious Hope." Hypatia: A Journal of Feminist Philosophy 30 (2015): 597-612. [CrossRef]

43. DeYoung, Rebecca Konyndyk. "Practicing Hope." Res Philosophica 91 (2014): 387-410. [CrossRef]

44. Kadlac, Adam. "The Virtue of Hope." Ethical Theory and Moral Practice 18 (2015): 337-54. [CrossRef]

45. Döring, Sabine. “What May I Hope? Why It Can Be Rational to Rely on One's Hope." European Journal for Philosophy of Religion 6 (2014): 117-29.

46. Romano, Claude. "Awaiting." In Phenomenology and Eschatology: Not Yet in the Now. Edited by Neal DeRoo and John Panteleimon Manoussakis. Translated by Ryan Coyne. Farnham and Burlington: Ashgate, 2009, pp. 35-52.

47. Romano, Calude. Event and Time. Translated by Stephen E. Lewis. New York: Fordham University Press, 2014.

48. Kierkegaard, Søren. Works of Love. Edited and translated by Howard V. Hong and Edna H. Hong. Princeton: Princeton University Press, 1995.

49. Chrétien, Jean-Louis. The Unforgettable and the Unhoped for. Translated by Jeffrey Bloechl. New York: Fordham University Press, 2002.

50. Simmons, J. Aaron. "Personally Speaking...: Kierkegaardian Postmodernism and the Messiness of Religious Existence." International Journal of Philosophical Studies 24 (2016): 685-703. [CrossRef]

51. Chrétien, Jean-Louis. The Call and the Response. Translated by Anne A. Davenport. New York: Fordham University Press, 2004.

52. Chrétien, Jean-Louis. Under the Gaze of the Bible. Translated by John Marson Dunaway. New York: Fordham University Press, 2015.

53. Kierkegaard, Søren. Fear and Trembling and Repetition. Edited and translated by Howard V. Hong and Edna H. Hong. Princeton: Princeton University Press, 1983.

(C) 2017 by the author. Licensee MDPI, Basel, Switzerland. This article is an open access article distributed under the terms and conditions of the Creative Commons Attribution (CC BY) license (http:/ / creativecommons.org/licenses/by/4.0/). 